\title{
The Role of Proaccelerin in Human Blood Coagulation. Evi- dence that Proaccelerin Is Converted to a Prothrombin- converting Principle by Activated Stuart Factor: With Notes on the Anticoagulant Action of Soybean Trypsin Inhibitor, Protamine Sulfate, and Hexadimethrine Bromide *
}

\author{
Robert T. Breckenridge $\dagger$ and Oscar D. Ratnoff $\ddagger$ \\ (From the Department of Medicine, Western Reserve University School of Medicine and \\ University Hospitals of Cleveland, Cleveland, Ohio)
}

In his original description of a patient with parahemophilia and his studies on the nature of the defect, Owren (1) proposed that the missing factor, proaccelerin (Factor V), was converted, in the presence of calcium, into a prothrombinconverting substance ("prothrombinase," Factor VI) by the action of tissue thromboplastin. Other investigators, notably Ware and Seegers (2) in a series of studies that they summarized in 1948, concluded that proaccelerin was converted to an active substance, sometimes called "accelerin," by thrombin and that the "accelerin" so formed was an accessory factor during prothrombin conversion and was not essential to this process.

The exact role of proaccelerin in human blood coagulation has not been settled with certainty. Several investigators (3-6) supported Ware and Seegers' hypothesis, but others (7-9) propose that prothrombin cannot be converted to thrombin in the absence of proaccelerin and that proaccelerin manifests its action after activation by some clotting factor other than thrombin (10).

Previous studies from this laboratory on the site of action of a circulating anticoagulant found

* Submitted for publication August 7, 1964 ; accepted November 2, 1964.

Supported in part by research grant HE 01661 from the National Heart Institute, in part by a grant from the American Heart Association, and in part by a grant from the Cleveland Area Heart Association.

†George and Anna Bishop Fellow in Medicine.

$¥$ Career Investigator of the American Heart Association. in disseminated lupus erythematosus (9) provided evidence that the activation of Stuart factor (Factor $\mathrm{X}$ ) preceded the participation of proaccelerin in coagulation and suggested that proaccelerin is converted into a "prothrombinconverting principle" by activated Stuart factor in the presence of phospholipid.

The studies reported here are an extension of the investigation of proaccelerin's role during human coagulation and the effects of some coagulation inhibitors on that role. Our observations indicate that proaccelerin is the substrate for the enzymatic activity of activated Stuart factor and that the product formed by their interaction is the substance responsible for the conversion of prothrombin to thrombin. The interaction of activated Stuart factor and proaccelerin is blocked by the action of an anticoagulant found in disseminated lupus erythematosus (9), by soybean trypsin inhibitor, protamine sulfate, and hexadimethrine bromide (Polybrene).

\section{Methods}

Citrated and oxalated plasmas were obtained from normal persons and from patients with various coagulation defects by previously described methods (11). These plasmas were used immediately or stored in siliconecoated Lusteroid containers at $-20^{\circ} \mathrm{C}$ until used. These plasmas were "cell-poor" unless otherwise stated.

Crude Stuart factor was prepared as a calcium phosphate eluate of prothrombin-deficient serum from a patient with severe Christmas disease or from normal people. Both preparations gave identical results in the experiments to be reported. The blood was allowed to clot at room temperature in the presence of $\frac{1}{30}$ its volume of tis- 
sue thromboplastin, 1 incubated at room temperature for 24 hours, and centrifuged at $2,100 \times g$ for 15 minutes. The supernatant serum was incubated at room temperature for an additional 24 hours. This serum was decalcified by the addition of $\frac{1}{10}$ its volume of $0.1 \mathrm{M}$ sodium oxalate and then adsorbed with $10 \mathrm{mg}$ calcium phosphate (powdered) ${ }^{2}$ per $\mathrm{ml}$ at room temperature with constant stirring. The calcium phosphate was separated by centrifugation at $2,100 \times g$ for 10 minutes, washed three times with twice the original serum volume of isotonic saline solution, and eluted twice with a volume of $0.13 \mathrm{M}$ trisodium citrate solution equal to one-half the original serum volume. After dialysis in cellophane casings 3 against 200 times its volume of imidazole buffer for 24 hours at $4^{\circ} \mathrm{C}$, the solution, after dilution to the desired concentration in imidazole buffer, served as the source of Stuart factor in the experiments to be described. This preparation contained Factor VII (pro-SPCA) and traces of PTA (plasma thromboplastin antecedent, Factor XI) and Hageman factor (Factor XII) in addition to Stuart factor, but was free of detectable proaccelerin, prothrombin, and fibrinogen. The preparation of Stuart factor may well have been partially activated during its preparation. It was further activated by incubation with Russell's viper venom and calcium as discussed subsequently.

Crude prothrombin was prepared from bentonite-adsorbed citrated plasma by a modification of the method of Soulier (12) and Hougie (13). Fresh citrated human plasma was adsorbed twice with bentonite (powdered) 4 at a concentration of $15 \mathrm{mg}$ bentonite per $\mathrm{ml}$ plasma. The mixture was centrifuged at $2,100 \times g$ for 20 minutes after each adsorption and the final supernatant plasma fraction dialyzed against 100 times its volume of Tris-oxalate buffer for 24 hours at $4^{\circ} \mathrm{C}$. The plasma fraction was then adsorbed with $10 \mathrm{mg}$ calcium phosphate per $\mathrm{ml}$ and centrifuged at $2,100 \times g$ for $10 \mathrm{~min}$ utes. The sedimented calcium phosphate was treated in the same manner as that used for the preparation of the crude Stuart factor. The final protein solution contained prothrombin and less than $1 \%$ of the original plasma concentration of Stuart factor and proaccelerin. It was free of other detectable clotting factors.

Fibrinogen was prepared from Cutter Parenogen, ${ }^{5}$ which is Fraction I of Cohn. One $\mathbf{g}$ of this preparation was dissolved in $25 \mathrm{ml}$ of distilled water and then adsorbed with $\frac{1}{10}$ its volume of concentrated aluminum hydroxide gel. After centrifugation at $2,100 \times g$ for 10 minutes, the supernatant protein solution was dialyzed against $1 \mathrm{~L}$ of imidazole buffer for 24 hours at $4^{\circ} \mathrm{C}$ and then filtered through Whatman 1 filter paper. This solu-

\footnotetext{
1 Bacto thromboplastin, Difco Laboratories, Detroit, Mich.

2 J. T. Baker Chemical Co., Phillipsburg, N. J.

3 Visking Co., Chicago, Ill.

4 Pro-Labo, 12 Rue Pelie, Paris XI', France.

${ }^{5}$ Kindly supplied by the Cutter Laboratories, Berkeley, Calif:
}

tion contained no detectable coagulation factors other than fibrinogen.

Crude proaccelerin was prepared from fresh oxalated human plasma by modification of a previously reported technique (9). Calcium chloride was used to stabilize the final product as suggested by several investigators $(10,14)$. This plasma was used immediately after it was obtained. It was adsorbed three times with $10 \mathrm{mg}$ calcium phosphate per $\mathrm{ml}$ of plasma and centrifuged at $2,100 \times g$ for 10 minutes after each adsorption. The thrice-adsorbed supernatant plasma was fractionated at $4^{\circ} \mathrm{C}$ with ammonium sulfate. A solution of neutral ammonium sulfate, saturated at $4^{\circ} \mathrm{C}$, was added to the plasma dropwise until the desired concentration was reached. The mixture was allowed to stand at this concentration for 15 minutes and then centrifuged. The protein fraction soluble at $25 \%$ saturation and insoluble at $50 \%$ saturation was dissolved in a volume of distilled water equal to $\frac{1}{20}$ the original plasma volume and dialyzed against cold, running tap water for 20 minutes. This fraction was then dialyzed against 200 times its volume of sodium acetate buffer containing $0.01 \mathrm{M}$ calcium chloride for 5 hours at $4^{\circ} \mathrm{C}$. The precipitate that formed was dissolved in a volume of $0.1 \mathrm{M}$ calcium chloride equal to $\frac{1}{20}$ of the original plasma volume and stored in Lusteroid containers at $-70^{\circ} \mathrm{C}$ until used. In the experiments in which the calcium requirement of the system was to be tested, the calcium was omitted from the dialysis, and the final product was dissolved in a volume of $0.1 \mathrm{M}$ sodium acetate buffer $\mathrm{pH} 5.4$ equal to $\frac{1}{2} \sigma$ of the original plasma volume and stored at $-70^{\circ} \mathrm{C}$ until used. The resultant solution, or dilution of this solution in imidazole buffer, served as the crude proaccelerin in the experiments to be described. This preparation was free of detectable fibrinogen, Stuart factor, or prothrombin, but no attempt was made to free it from Hageman factor and PTA.

Imidazole buffer was prepared by dissolving imidazole ${ }^{6}$ in distilled water to give a molarity of 0.15 . The final $\mathrm{pH}$ was adjusted to 6.8 by titration with concentrated hydrochloric acid.

Gliddex-P, a crude preparation of soybean phosphatides, was prepared as a $0.1 \%$ suspension in saline as in a previous publication (15). It was diluted $\frac{1}{10}$ in imidazole buffer before use.

Tris-oxalate buffer contained $850 \mathrm{ml}$ of $0.13 \mathrm{M}$ Tris buffer ( $\mathrm{pH} \mathrm{7.4)}$ ) and $150 \mathrm{ml} 0.1 \mathrm{M}$ sodium oxalate per L.

Sodium acetate buffers, $0.01 \mathrm{M}$ and $0.1 \mathrm{M} \mathrm{pH} 5.2$, were prepared as previously reported (11).

Cation exchange resin, Amberlite IRC-50 in the hydrogen cycle, was converted to the sodium cycle as previously described (16).

Two preparations of aluminum hydroxide gel were used. Concentrated aluminum hydroxide gel was undiluted Amphojel. ${ }^{7}$ Dilute aluminum hydroxide gel $^{5}$ was a

6 Nutritional Biochemicals Corp., Cleveland, Ohio.

7 Without flavor, furnished through the courtesy of Wyeth Laboratories, Philadelphia, $\mathrm{Pa}$. 
TABLE I

Russell's viper venom coagulation system*

\begin{tabular}{lll}
\hline \hline \multicolumn{1}{c}{ Stage I } & \multicolumn{1}{c}{ Stage II } \\
\hline $0.1 \mathrm{ml}$ Russell's viper venom & $+0.1 \mathrm{ml}$ proaccelerin $+0.1 \mathrm{ml}$ prothrombin $\dagger$ \\
$0.1 \mathrm{ml}$ Stuart factor & $0.2 \mathrm{ml}$ fibrinogen \\
$0.1 \mathrm{ml}$ calcium chloride & \\
$0.1 \mathrm{ml}$ Gliddex-P & \\
\hline
\end{tabular}

* Modified from Macfarlane (17). Performed in uncoated Pyrex tubes at $37^{\circ} \mathrm{C}$.

† Soybean trypsin inhibitor was added at various stages; but in all experiments, the final concentration, in stage III after all dilutions, was $62.5 \mu \mathrm{g}$ per ml (see text).

commercial suspension diluted with water. The concentration of aluminum hydroxide gels, as provided by their manufacturers, is given in terms of aluminum oxide. The dilute gel contained $0.55 \%$ and the concentrated gel $4 \%$ aluminum oxide; the latter also contained small, unspecified quantities of glycerin and sodium benzoate (11).

Soybean trypsin inhibitor (five times crystallized) ${ }^{6}$ was dissolved in imidazole buffer in the desired concentration, as were protamine sulfate $(1 \%),{ }^{8}$ Polybrene (hexadimethrine bromide), ${ }^{9}$ heparin (heparin sodium, 1,000 U.S.P. U per $\mathrm{ml}$ ), ${ }^{10}$ Liquoid (sodium polyanetholesulfonate), ${ }^{11}$ and TAMe ( $p$-toluene sulfonyl-L-arginine methyl ester hydrochloride. ${ }^{12}$

Russell's viper venom ${ }^{13}$ was diluted to a concentration of $1: 200,000$ in imidazole buffer.

Calcium chloride was prepared in a $0.025 \mathrm{M}$ solution in distilled water.

Bovine thrombin ${ }^{14}$ was diluted to 10 National Institutes of Health $\mathrm{U}$ thrombin per $\mathrm{ml}$ in barbital-saline. This thrombin solution was then absorbed with $\frac{1}{10}$ its volume of dilute aluminum hydroxide gel and centrifuged at $2,100 \times g$ for 5 minutes. The supernatant protein solution was used as a source of thrombin after suitable dilution in barbital-saline or imidazole buffer.

All clotting studies were done in uncoated Pyrex tubes with an internal diameter of $8 \mathrm{~mm}$ or in silicone-coated Lusteroid tubes with an internal diameter of $11 \mathrm{~mm}$.

Assays for Hageman factor (Factor XII), PTA (plasma thromboplastin antecedent, Factor XI), Christmas factor (Factor IX), Factor VII (pro-SPCA), prothrombin, proaccelerin (Factor V), antihemophilic factor (Factor VIII), and fibrinogen were performed by previously published methods $(11,15)$. These methods involve the use of deficient plasmas as substrates for the assays. The Stuart factor (Factor X) assay was done in the same manner as the Factor VII assay utilizing a plasma deficient in Stuart factor as the substrate plasma.

The activation of Stuart factor was accomplished by

8 Eli Lilly and Co., Indianapolis, Ind.

9 Abbott Laboratories, North Chicago, Ill.

10 Upjohn Co., Kalamazoo, Mich.

11 Roche Products Ltd., Welwyn Garden City, England.

12 Mann Research Laboratories, New York, N. Y.

13 Burroughs Wellcome \& Co., Tuckahoe, N. Y.

14 Parke, Davis \& Co., Detroit, Mich. incubating Russell's viper venom and calcium ions with the crude Stuart factor preparations as originally described by Macfarlane (17) and modified in this laboratory (9). Six-tenths $\mathrm{ml}$ of the venom, $0.6 \mathrm{ml}$ of crude Stuart factor, $0.6 \mathrm{ml}$ of Gliddex-P suspension, and $0.6 \mathrm{ml}$ of $0.025 \mathrm{M}$ calcium chloride were incubated in Lusteroid tubes at $37^{\circ} \mathrm{C}$ for specified intervals. After a suitable time, usually 90 seconds, the incubation mixture was put into a melting ice water bath. This mixture served as crude activated Stuart factor.

The activation of proaccelerin was performed by incubating a series of Pyrex tubes, each containing $0.2 \mathrm{ml}$ of the crude activated Stuart factor and $0.1 \mathrm{ml}$ of crude proaccelerin at $37^{\circ} \mathrm{C}$. At intervals, successive tubes were placed in an ice water bath. One-tenth $\mathrm{ml}$ of the mixture was then diluted in $0.9 \mathrm{ml}$ of imidazole buffer containing $0.005 \mathrm{M}$ calcium, $0.001 \%$ phospholipid, and $100 \mu \mathrm{g}$ per $\mathrm{ml}$ of soybean trypsin inhibitor. The phospholipid was added to the final stage to keep its concentration constant throughout the experiments. The calcium is necessary for the conversion of prothrombin to thrombin by the prothrombin-converting principle as discussed subsequently. The clot-promoting activity generated was tested by adding $0.5 \mathrm{ml}$ of the above dilution to $0.1 \mathrm{ml}$ of the crude prothrombin and $0.2 \mathrm{ml}$ of fibrinogen. The final concentration of soybean trypsin inhibitor was 62.5 $\mu \mathrm{g}$ per $\mathrm{ml}$ in all experiments after the addition of the prothrombin and fibrinogen. The clotting time was recorded as that time elapsing between the addition of the prothrombin and fibrinogen to the appearance of the first fibrin strands.

To test the dependence of the system on the various clotting factors present, each clotting factor was omitted and the effect of its omission on the final clotting time quantified. In addition, known coagulation inhibitors were added, and the effect on the final clotting time was measured.

The coagulation system tested is shown in Table I. The incubation times shown and the sequence illustrated were determined experimentally and have been published previously (9). They are in essential agreement with those of Macfarlane (17). The system used in these experiments takes advantage of the observation, recorded later in this paper, that soybean trypsin inhibitor blocks the interaction of activated Stuart factor and proaccelerin but does not inhibit clotting, at the concentrations tested, 
TABLE II

Effect of deletion of clotting factors on the Russell's viper venom coagulation system

\begin{tabular}{|c|c|c|}
\hline Stage I & Stage III & $\underset{\text { time* }}{\text { Clotting }}$ \\
\hline $\begin{array}{l}0.1 \mathrm{ml} \text { Russell's viper venom } \\
0.1 \mathrm{ml} \text { Stuart factor } \\
0.1 \mathrm{ml} \text { calcium chloride } \\
0.1 \mathrm{ml} \text { Gliddex-P }\end{array}$ & 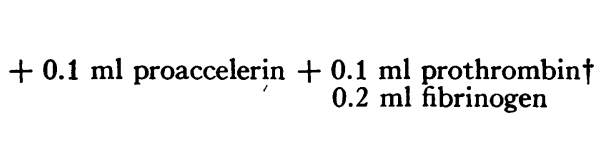 & seconds \\
\hline $\begin{array}{l}0.1 \mathrm{ml} \text { buffer } \\
0.1 \mathrm{ml} \text { Stuart factor } \\
0.1 \mathrm{ml} \text { calcium chloride } \\
0.1 \mathrm{ml} \text { Gliddex-P }\end{array}$ & $+0.1 \mathrm{ml}$ proaccelerin $+\underset{0.1 \mathrm{ml} \text { prothrombin } \dagger}{0.2 \mathrm{ml} \text { fibrinogen }}$ & $>600$ \\
\hline $\begin{array}{l}0.1 \mathrm{ml} \text { Russell's viper venom } \\
0.1 \mathrm{ml} \text { buffer } \\
0.1 \mathrm{ml} \text { calcium chloride } \\
0.1 \mathrm{ml} \text { Gliddex-P }\end{array}$ & $+0.1 \mathrm{ml}$ proaccelerin $+\underset{0.1 \mathrm{ml} \text { prothrombin } \dagger}{0.2 \mathrm{ml} \text { fibrinogen }}$ & $>600$ \\
\hline $\begin{array}{l}0.1 \mathrm{ml} \text { Russell's viper venom } \\
0.1 \mathrm{ml} \text { Stuart factor } \\
0.1 \mathrm{ml} \text { buffer } \\
0.1 \mathrm{ml} \text { Gliddex-P }\end{array}$ & $+0.1 \mathrm{ml}$ proaccelerin $+\begin{array}{r}0.1 \mathrm{ml} \text { prothrombin } \dagger \\
0.2 \mathrm{ml} \text { fibrinogen }\end{array}$ & $>600$ \\
\hline $\begin{array}{l}0.1 \mathrm{ml} \text { Russell's viper venom } \\
0.1 \mathrm{ml} \text { Stuart factor } \\
0.1 \mathrm{ml} \text { calcium chloride } \\
0.1 \mathrm{ml} \text { buffer }\end{array}$ & $+0.1 \mathrm{ml}$ proaccelerin $+\begin{array}{r}0.1 \mathrm{ml} \text { prothrombin } \dagger \\
0.2 \mathrm{ml} \text { fibrinogen }\end{array}$ & $>600$ \\
\hline $\begin{array}{l}0.1 \mathrm{ml} \text { Russell's viper venom } \\
0.1 \mathrm{ml} \text { Stuart factor } \\
0.1 \mathrm{ml} \text { calcium chloride } \\
0.1 \mathrm{ml} \text { Gliddex-P }\end{array}$ & $\begin{array}{l}+0.1 \mathrm{ml} \text { prothrombin } \dagger \\
0.2 \mathrm{ml} \text { fibrinogen }\end{array}$ & $>600$ \\
\hline $\begin{array}{l}0.1 \mathrm{ml} \text { Russell's viper venom } \\
0.1 \mathrm{ml} \text { Stuart factor } \\
0.1 \mathrm{ml} \text { calcium chloride } \\
0.1 \mathrm{ml} \text { Gliddex-P }\end{array}$ & $+0.1 \mathrm{ml}$ proaccelerin $+\begin{array}{l}0.1 \mathrm{ml} \text { buffer } \\
0.2 \mathrm{ml} \text { fibrinogen }\end{array}$ & $>600$ \\
\hline
\end{tabular}

* Incubation was carried out at $37^{\circ} \mathrm{C}$ in uncoated Pyrex tubes.

$\dagger$ The final clotting mixture in Stage III contained soybean trypsin inhibitor in a concentration of $62.5 \mu \mathrm{g}$ per $\mathrm{ml}$ (see text).

once these two factors have completed their interaction. Soybean trypsin inhibitor was therefore added in a final concentration of $62.5 \mu \mathrm{g}$ per $\mathrm{ml}$ to stop the further interaction of activated Stuart factor and proaccelerin during assay of the clot-promoting effect of the prothrombinconverting substance on prothrombin and fibrinogen.

The calcium requirement of this system was tested by incubating the reagents shown in Table $I$ for the specified times shown and then adsorbing the product with $\frac{1}{3} \mathrm{vol} / \mathrm{vol}$ of Amberlite IRC-50 in the sodium cycle. This mixture was then centrifuged. The supernatant fluid was divided into equal parts, calcium added to one and not the other, and the remaining steps performed as described above and outlined in Table I. In this manner, it was possible to remove calcium from each step and determine the effect of this omission on the final clotting time obtained.

To test the effect of diisopropylphosphofluoridate (DFP) 15 on the prothrombin-converting principle, the activated Stuart factor and proaccelerin were allowed to

${ }^{15} \mathrm{~K}$ and $\mathrm{K}$ Laboratories, Long Island City, N. Y. interact at $37^{\circ} \mathrm{C}$ until maximal clot-promoting activity had generated. At this point the mixture was incubated with DFP for 5 minutes at $20^{\circ} \mathrm{C}$ in a concentration of DFP of $10^{-4} \mathrm{M}$. The control mixture was incubated in a similar manner with the buffer used to prepare the DFP. This concentration of DFP completely inactivated the clot-promoting activity of a solution of 10 N.I.H. U per $\mathrm{ml}$ of thrombin as tested on a substrate of fibrinogen.

All experiments other than the incubation with DFP and the studies of inhibitors described in Table IV were done on six or more occasions. The results given are typical of those obtained each time. The experiments in Table IV were done twice. The DFP experiment was done only once since it was essentially a confirmation of another study (18).

\section{Results}

For appreciable, thrombin formation to occur during the period of observation, all clotting factors listed had to be present. Table II illus- 
TABLE III

Effect of soybean trypsin inhibitor on the, evolution of the prothrombin-converting substance*

\begin{tabular}{c}
\hline $\begin{array}{c}\text { Clotting } \\
\text { time }\end{array}$ \\
seconds
\end{tabular}

1. Control system with buffer added 89.0

2. Soybean trypsin inhibitor $\dagger$ added before the activation of Stuart factor by Russell's viper venom

3. Soybean trypsin inhibitor $†$ addedafter the activation of Stuart factor by Russell's viper venom but before the addition of proaccelerin to the system

4. Soybean trypsin inhibitor $†$ added after active Stuart factor and proaccelerin have interacted and the prothrombinconverting principle has been formed

* Performed in uncoated Pyrex tubes at $37^{\circ} \mathrm{C}$.

$\dagger$ One-tenth $\mathrm{ml}$ of buffer containing soybean trypsin inhibitor was added to the generating mixtures at the various time intervals noted above. The concentration of soybean trypsin inhibitor was $90 \mu \mathrm{g}$ per ml during the activation of Stuart factor and $84 \mu \mathrm{g}$ per $\mathrm{ml}$ during the interaction of activated Stuart factor and proaccelerin. The final concentration of soybean trypsin inhibitor in all experiments was $62.5 \mu \mathrm{g}$ per $\mathrm{ml}$ (see text). trates that no detectable thrombin formed within 10 minutes in the absence of Stuart factor, venom, Gliddex-P, calcium, prothrombin, or proaccelerin, whereas when all these factors were present, prothrombin-converting activity evolved. The data shown on Table II were highly reproducible.

The effect of soybean trypsin inhibitor was to block the interaction of activated Stuart factor and proaccelerin, as is shown in Table III. This effect was demonstrable with final concentration of soybean trypsin inhibitor as low as $12.5 \mu \mathrm{g}$ per ml. The anticoagulant effect of this inhibitor could not be demonstrated once activated Stuart factor and proaccelerin had interacted and the prothrombin-converting principle had been formed. In addition, no antithrombic activity could be demonstrated with this inhibitor at a concentration of $62.5 \mu \mathrm{g}$ per $\mathrm{ml}$.

The anticoagulant effect of protamine sulfate, Polybrene, and TAMe is shown in Table IV. It can be seen from this table that the reaction between activated Stuart factor and proaccelerin is inhibited by Polybrene and partially inhibited

TABLE IV

Effect of inhibitors on the interaction of activated Stuart factor and proaccelerin

\begin{tabular}{|c|c|c|c|c|}
\hline \multirow[b]{2}{*}{ Inhibitor } & \multirow[b]{2}{*}{$\begin{array}{l}\text { Concentration of } \\
\text { inhibitor in } \\
\text { stage } A^{*}\end{array}$} & \multicolumn{3}{|c|}{ Clotting time } \\
\hline & & $\begin{array}{l}\text { Stage A: In- } \\
\text { hibitor added } \\
\text { before the } \\
\text { interaction of } \\
\text { activated } \\
\text { Stuart factor } \\
\text { and proac- } \\
\text { celerin }\end{array}$ & $\begin{array}{l}\text { Stage B: In- } \\
\text { inhibitor added } \\
\text { after the } \\
\text { interaction of } \\
\text { activated } \\
\text { Stuart factor } \\
\text { and proac- } \\
\text { celerin had } \\
\text { taken place }\end{array}$ & $\begin{array}{l}\text { Control } \\
\text { No inhibitor }\end{array}$ \\
\hline 1. Heparin & $\begin{array}{l}0.024 \mu \mathrm{g} / \mathrm{ml} \\
(0.003 \mathrm{U} / \mathrm{ml})\end{array}$ & 129 & $\begin{array}{c}\text { seconds } \\
130\end{array}$ & 128 \\
\hline $\begin{array}{l}\text { 2. TAMe } \\
\text { ( } p \text {-toluene sulfonyl- } \\
\text { L-arginine methyl } \\
\text { ester } \mathrm{HCl} \text { ) }\end{array}$ & $0.008 \mathrm{M}$ & 600 & 360 & 164 \\
\hline 3. Protamine sulfate & $2 \mu \mathrm{g} / \mathrm{ml}$ & 200 & 140 & 142 \\
\hline $\begin{array}{l}\text { 4. Liquoid (sodium } \\
\text { polyanetholesulfonate) }\end{array}$ & $0.2 \mu \mathrm{g} / \mathrm{ml}$ & 135 & 140 & 135 \\
\hline $\begin{array}{l}\text { 5. Polybrene } \\
\text { (hexadimethrine } \\
\text { bromide) }\end{array}$ & $20 \mu \mathrm{g} / \mathrm{ml}$ & 600 & 130 & 130 \\
\hline
\end{tabular}

* The mixture tested in stage A (the interaction of activated Stuart factor and proaccelerin) was diluted tenfold at stage $\mathrm{B}$ (the interaction of the prothrombin-converting principle; prothrombin and fibrinogen). The concentration of the inhibitors tested in stage $A$ was adjusted so that these substances would not interfere with the subsequent reactions in stage B. Under the condition used, this proved impossible in the case of TAMe. 


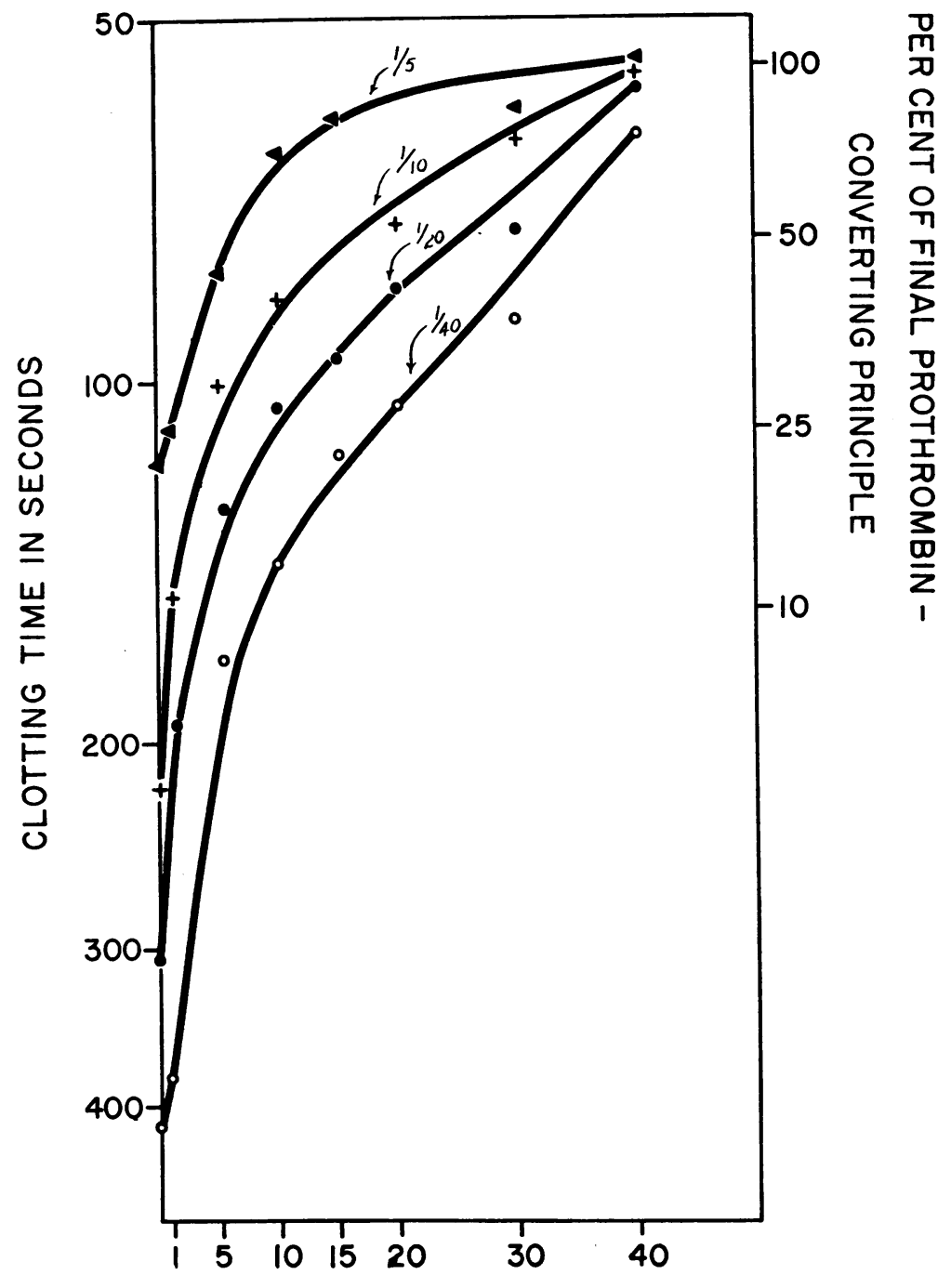

\section{TIME OF INCUBATION IN MINUTES}

Fig. 1. Effect of varying the concentration of activated Stuart FACTOR UPON THE DEVELOPMENT OF PROTHROMBIN-CONVERTING ACTIVITY. Crude Stuart factor, activated by treatment with Russell's viper venom and calcium, was incubated with concentrated crude proaccelerin in the presence of phospholipid. The clot-promoting activity that formed was tested by addition of a dilution of this mixture to prothrombin and fibrinogen in the presence of soybean trypsin inhibitor. In this experiment, the concentration of crude proaccelerin was kept constant, and the concentration of activated Stuart factor varied eightfold; its concentration is expressed as the comparable dilution of the plasma from which it was prepared. The results were quantified in terms of per cent of the final prothrombin-converting principle by serial dilution of the product formed by the interaction of activated Stuart factor at a $\frac{1}{3}$ dilution relative to the serum from which it was prepared and proaccelerin for 40 minutes. 


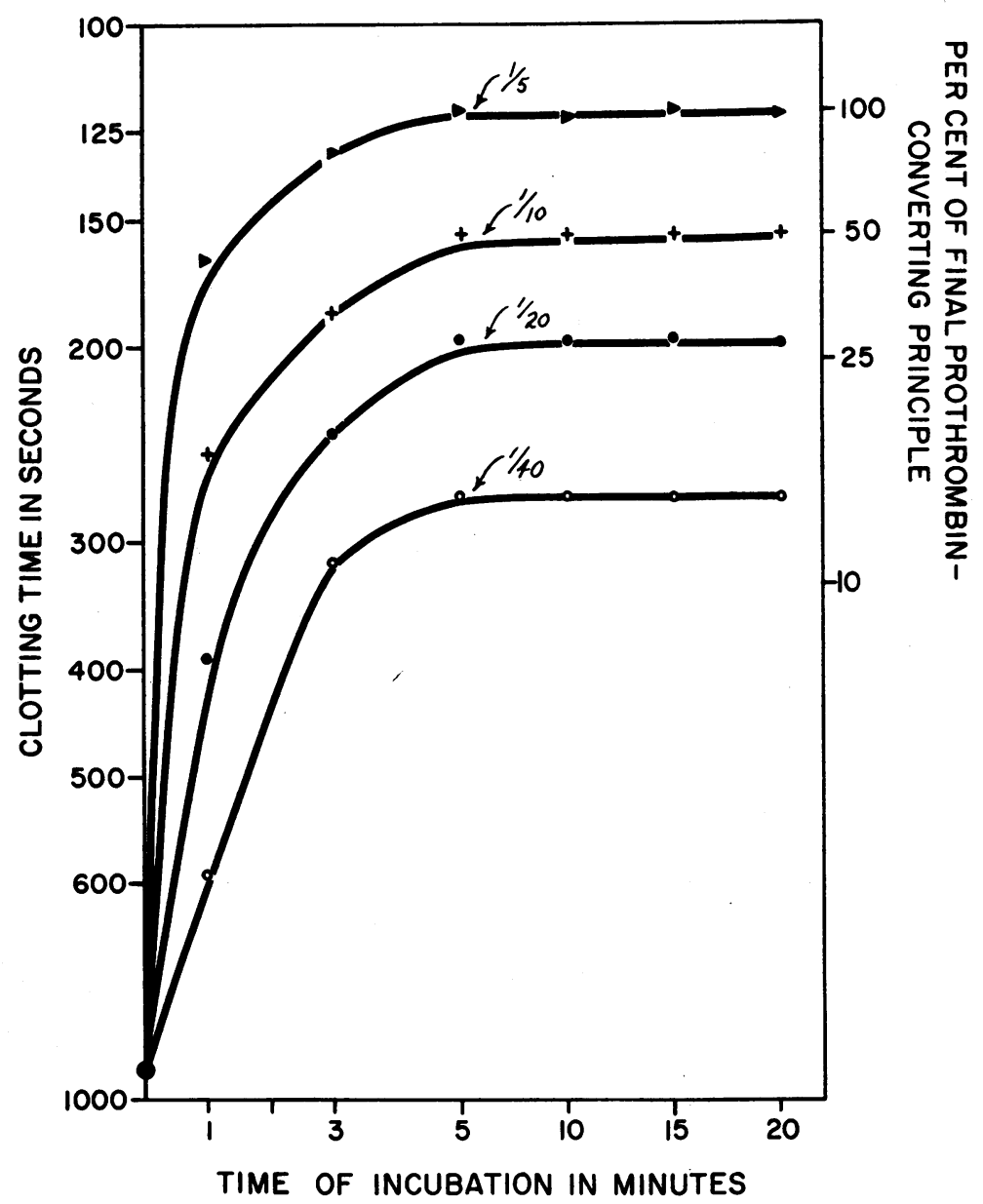

Fig. 2. EFfect varying the CONCENTRATION OF PROACCELERIN UPON THE DEVELOPMENT OF PROTHROMBIN-CONVERTING ACTIVITy. Crude Stuart factor, activated by treatment with Russell's viper venom and calcium, was incubated with crude proaccelerin in the presence of phospholipid. The clot-promoting activity that formed was tested by addition of a dilution of this mixture to prothrombin and fibrinogen in the presence of soybean trypsin inhibitor. In this experiment, the concentration of activated Stuart factor was kept constant at a dilution of $\frac{1}{20}$ of the serum from which it was prepared, and the concentration of crude proaccelerin varied eightfold at concentrations expressed as dilutions of the solution from which it was prepared (see text). The results were quantified in terms of per cent of the final prothrombinconverting principle by serial dilution of the product formed by the interaction of activated Stuart factor and the $\frac{1}{b}$ dilution of proaccelerin.

by protamine sulfate. There is some anticoagulant action of TAMe at this step, but in addition there is an inhibitory action by this compound later in clotting as manifested by its inhibition of stage B in Table IV. It can also be noted from this table that heparin and Liquoid were without effect on the activated Stuart factor-proaccelerin interaction in stage $\mathrm{A}$ under the conditions tested.
The effect of varying the concentration of activated Stuart factor upon the development of prothrombin-converting activity can be seen in Figure 1. Crude Stuart factor, activated by treatment with Russell's viper venom and calcium, was incubated with undiluted crude proaccelerin in the presence of phospholipid. The clot-promoting activity that formed was tested by adding the 
diluted mixture to prothrombin and fibrinogen in the presence of soybean trypsin inhibitor as described in the Methods section. When the concentration of proaccelerin was kept constant and the concentration of activated Stuart factor varied over an eightfold range, the yield of clot-promoting activity was essentially unaffected. The rate at which this clot-promoting activity was formed, however, was a function of the concentration of activated Stuart factor present in the generating mixture.

The effect of varying the concentration of proaccelerin is demonstrated in Figure 2. In this experiment the concentration of activated Stuart factor was maintained constant at a $1 / 20$ dilution relative to the original serum while the concentration of proaccelerin was varied over an eightfold range. Again, soybean trypsin inhibitor was included in the buffer solution used as a diluent after the interaction of Stuart factor and proaccelerin to halt the further evolution of clotpromoting activity during the assay. Under these conditions, the clot-promoting activity developed was directly related to the concentration of proaccelerin in the generating mixture. The rate of generation of this activity was affected slightly, but the major effect was on the amount of activity generated. In these experiments, the concentration of proaccelerin was much less than in those in which the concentration of activated Stuart factor was varied. This may explain the shorter time needed to activate proaccelerin fully when its concentration was varied.

Under the circumstances of the experiments wherein the concentration of proaccelerin was varied, clot-promoting activity was maximal after activated Stuart factor and proaccelerin had interacted for 5 minutes. At this time, the logarithm of the clotting time was an inverse function of the logarithm of the concentration of proaccelerin in the initial mixture (Figure 3 ).

Phospholipid was necessary for the generation of clot-promoting activity (Table II). The addition of the phospholipid after the Stuart factor had been activated by the venom gave clotting times identical with those obtained when it was added before Stuart factor's activation. When the phospholipid was added after the proaccelerin had been added, the clotting time lengthened. Thus the phospholipid appeared not to be neces-

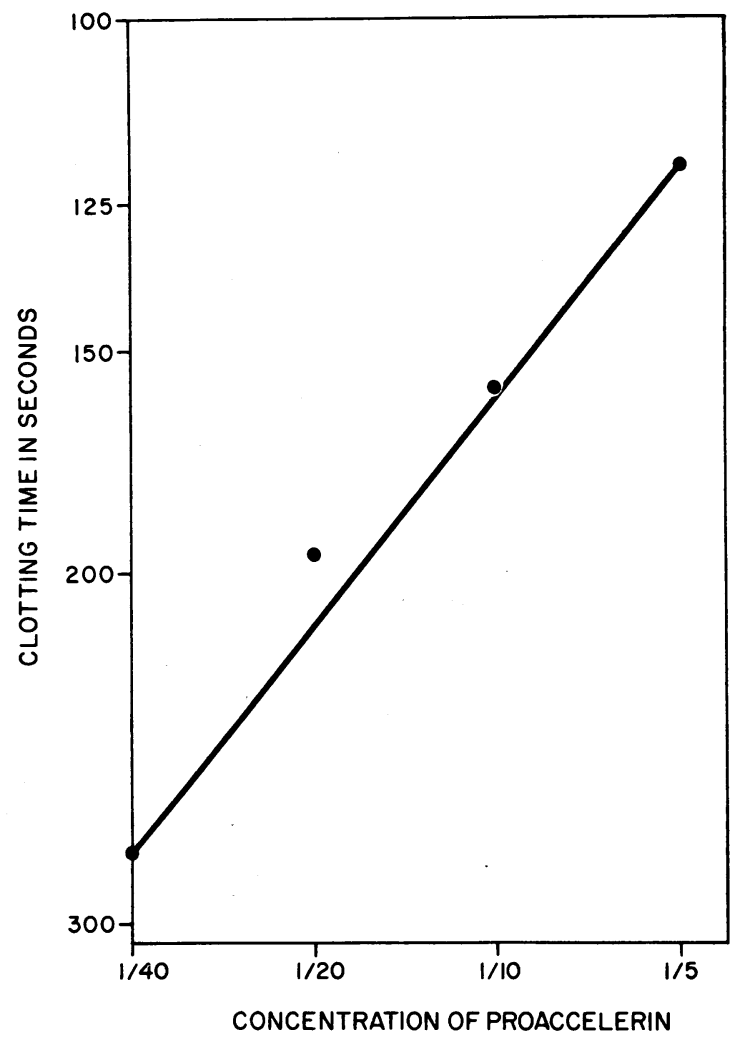

Fig. 3. Relationship Between the concentration OF PROACCELERIN AND THE EVENTUAL CLOT-PROMOTING ACTIVITY GENERATED. Crude Stuart factor, activated by treatment with Russell's viper venom and calcium, was incubated with crude proaccelerin in the presence of phospholipid. The clot-promoting activity that formed was tested by addition of dilutions of this mixture to prothrombin and fibrinogen in the presence of soybean trypsin inhibitor. The logarithm of the clotting times at 5 minutes (as seen in Figure 2) was plotted, on doubly logarithmic paper, against the logarithm of the original concentration of proaccelerin in the mixture.

sary for the activation of the Stuart factor but seemed to be needed for reaction between activated Stuart factor and proaccelerin. This confirms results from this (9) and other laboratories $(17,19)$.

Macfarlane (17) and Williams and Esnouf (20, 21) have demonstrated that calcium is necessary for the activation of Stuart factor by Russell's viper venom. We have found that the activation of proaccelerin by activated Stuart factor proceeds in the presence of citrate ions. However, when Amberlite IRC-50 is used to remove the calcium ions, calcium seems to be needed for the interac- 
tion of activated Stuart factor and proaccelerin as noted in Table $\mathrm{V}$.

Clot-promoting activity did not evolve when adsorbed bovine thrombin was incubated with proaccelerin, phospholipid, and calcium ions in the absence of Stuart factor and venom (Table VI). This is in agreement with the results obtained by Surgenor, Wilson, and Henry (10). In addition, thrombin, in the concentration used, did not potentiate the clot-promoting activity when added to the complete system in the presence of Stuart factor and venom (Table VI), confirming the results obtained by Peden and Peacock (19). The initial concentration of thrombin ranged from 1 to $10 \mathrm{U}$. In these experiments, after the incubation of thrombin and proaccelerin, the mixture was diluted before its addition to the prothrombin-fibrinogen mixture so that the final concentration of thrombin would not clot fibrinogen in 10 minutes.

The clot-promoting activity formed during the interaction of activated Stuart factor, phospholipid, and proaccelerin was lost when the mixture was adsorbed with $\frac{1}{10}$ its volume of $0.55 \%$ aluminum hydroxide gel. There was no detectable proaccelerin activity in the supernatant solution after adsorption when assayed specifically for this clotting factor.

TABLE V

Effect of calcium on the evolution of the prothrombin-converting substance*

\begin{tabular}{|c|c|c|}
\hline & & $\underset{\text { time }}{\text { Clotting }}$ \\
\hline $\begin{array}{l}\text { Amberlite-adsorbed activated } \\
\text { Stuart factor } \\
\text { + Calcium } \\
\text { + Proaccelerin }\end{array}$ & $\begin{array}{c}\text { 5-minute }+ \text { Prothrombin } \\
\text { incubation Fibrinogen } \\
\text { Calcium }\end{array}$ & seconds \\
\hline $\begin{array}{l}\text { Amberlite-adsorbed activated } \\
\quad \text { Stuart factor } \\
\text { + Buffer } \\
\text { + Proaccelerin }\end{array}$ & $\begin{array}{c}\text { 5-minute }+ \text { Prothrombin } \\
\text { incubation Fibrinogen } \\
\text { Calcium }\end{array}$ & 600 \\
\hline
\end{tabular}

* Crude Stuart factor was incubated with Russell's viper venom, cal cium chloride, and phospholipid for 4 minutes to provide maximal activation. This product was then adsorbed with $\frac{1}{3}$ vol of Amberlite IRC50 to remove the calcium and centrifuged. The supernatant solution was then divided in half; one-half was incubated for 5 minutes with proaccelerin in the presence of calcium, and one-half was incubated with proaccelerin without calcium added. At the end of this 5-minute period both products were diluted in buffer containing calcium, phospholipid, and soybean trypsin inhibitor at a concentration of $100 \mu \mathrm{g}$ per $\mathrm{ml}$. Prothrombin, fibrinogen, and calcium were added to both and the clotting times determined. The calcium concentrations were equal in both during the final reactions.
TABLE VI

Effect of thrombin on the evolution of the prothrombin-converting principle

\begin{tabular}{lc}
\hline \hline & $\begin{array}{c}\text { Clotting } \\
\text { time }\end{array}$ \\
\hline & seconds \\
Complete system + buffer & 53 \\
Complete system + thrombin* & 53 \\
System without venom + thrombin* & $>180$ \\
System without venom or Stuart factor & $>180$ \\
+ thrombin* & \\
\hline
\end{tabular}

* Ten N.I.H. U of adsorbed thrombin per $\mathrm{ml}$. The clotting time of equal parts of this adsorbed thrombin and fibrinogen was 10 seconds at $37^{\circ} \mathrm{C}$.

The prothrombin-converting principle formed by the interaction between activated Stuart factor and proaccelerin was not inactivated by DFP. When added to prothrombin and fibrinogen, the product of this interaction formed a clot in 50 seconds whether or not DFP had been added initially. This finding is similar to that reported by Spaet and Cintron (18).

\section{Discussion}

The data presented support the hypothesis that proaccelerin, in the presence of phospholipid, is converted into a "prothrombin-converting principle" by the action of activated Stuart factor. These data are in agreement with those of Hardisty (7) and Straub and Duckert (8).

Previous studies demonstrated that a circulating anticoagulant found in some cases of disseminated lupus erythematosus inhibited the interaction of activated Stuart factor and proaccelerin (9). The present study demonstrated that soybean trypsin inhibitor, protamine sulfate, and Polybrene also impede coagulation by acting at the same stage. From these observations, it may be concluded that the activation of Stuart factor precedes the participation of proaccelerin in coagulation, a conclusion that has been tentatively held by other investigators $(22,23)$.

The localization of the site of action of soybean trypsin inhibitor enabled us to determine the nature of the interaction of activated Stuart factor and proaccelerin. Mixtures of activated Stuart factor and proaccelerin could be incubated for varying lengths of time and their interaction impeded by the addition of soybean trypsin inhibitor. The clot-promoting activity generated could then 
be tested on a substrate of prothrombin and fibrinogen. The presence of the inhibitor prevented further reaction between the activated Stuart factor and proaccelerin during the period when the clot-promoting activity was being measured.

With this technique it was possible to demonstrate that the rate of generation of clot-promoting activity in a mixture of activated Stuart factor and proaccelerin was determined by the concentration of activated Stuart factor, whereas the magnitude of clot-promoting activity generated was dependent on the concentration of proaccelerin present. These experiments strongly suggest that activated Stuart factor is an enzyme that acts upon a substrate, proaccelerin, to evolve a "prothrombin-converting principle," presumably "activated proaccelerin." Although they do not eliminate the possibility that the prothrombinconverting principle is a complex of activated Stuart factor, phospholipid, proaccelerin, and calcium, this interpretation does not seem warranted from our data.

The stages of coagulation concerned with the conversion of prothrombin to thrombin have been a subject of controversy since 1904 when Bordet and Gengou (24) discovered that a factor in diluted serum, other than thrombin, accelerated thrombin formation. Milstone, in a masterly review of the literature in 1952 (25), suggested that the final prothrombin-converting substance be named thrombokinase, a term originated by Morawitz in 1904 (26). This substance was defined as an active substance generated during coagulation that converts prothrombin to thrombin in an enzymatic fashion. The analogy has been made between this substance and trypsin (27). Since Milstone's thrombokinase required no co-factors for its action, he distinguished it from the thromboplastins of Nolf (28) and Howell (29), which were defined as adjuvants to coagulation. A major problem has been whether the substance, thrombokinase, could be defined in terms of known clotting factors.

The problem seemed resolved when Owren, in 1947 (1), described proaccelerin (Factor V), which he said was converted to "prothrombinase" (Factor VI), the substance that converted prothrombin to thrombin, by the action of tissue thromboplastin and calcium. It became apparent, however, in subsequent studies (30) that the proaccelerin preparation originally described was contaminated with Factor VII and Stuart factor and that these contaminants might have been responsible for the clot-promoting activity Owren had noted.

Since Owren's discovery of Factor V there have been many studies undertaken to determine the exact sequence of events leading to the conversion of prothrombin to thrombin. Many investigators $(2-4,22,23,30,31)$, using bovine coagulation systems, concluded from rate studies that proaccelerin was not necessary for the conversion of prothrombin to thrombin, but was merely a cofactor for the conversion of prothrombin to thrombin by Stuart factor. Bovine proaccelerin, however, has somewhat different physiochemical characteristics than its human counterpart in that it is present in serum (2) and is adsorbed on alkaline earth in fairly substantial quantities (32). We have not been able to free bovine prothrombin or Stuart factor from significant traces of proaccelerin by chromatography on DEAE-cellulose (32). The contamination of bovine clotting factors may explain why the interpretation of experiments utilizing the bovine systems $(2-4,22,23,30,31,33)$ differs from those in which human clotting factors were used (7-9).

The characteristics of the prothrombin-converting principle generated by the interaction of activated Stuart factor and proaccelerin are similar to those proposed for thrombokinase by Milstone and associates $(25,27,34)$. The substance generated converted prothrombin to thrombin directly without cofactors other than calcium and in low concentration. In addition, it was heat labile and was adsorbed readily by alkaline earth.

Through the kindness of Dr. Milstone we were able to perform experiments with the clot-promoting substance he has isolated from bovine plasma (34). This substance corrected the defect in the plasma of a patient congenitally deficient in Stuart factor. Both phospholipid and proaccelerin were required to accomplish this correction (32). These data are then consistent with our hypothesis that the prothrombin-converting principle is derived from proaccelerin by the action of activated Stuart factor in the presence of phospholipid. This concept is presented pictorially in Figure 4, which represents the en- 

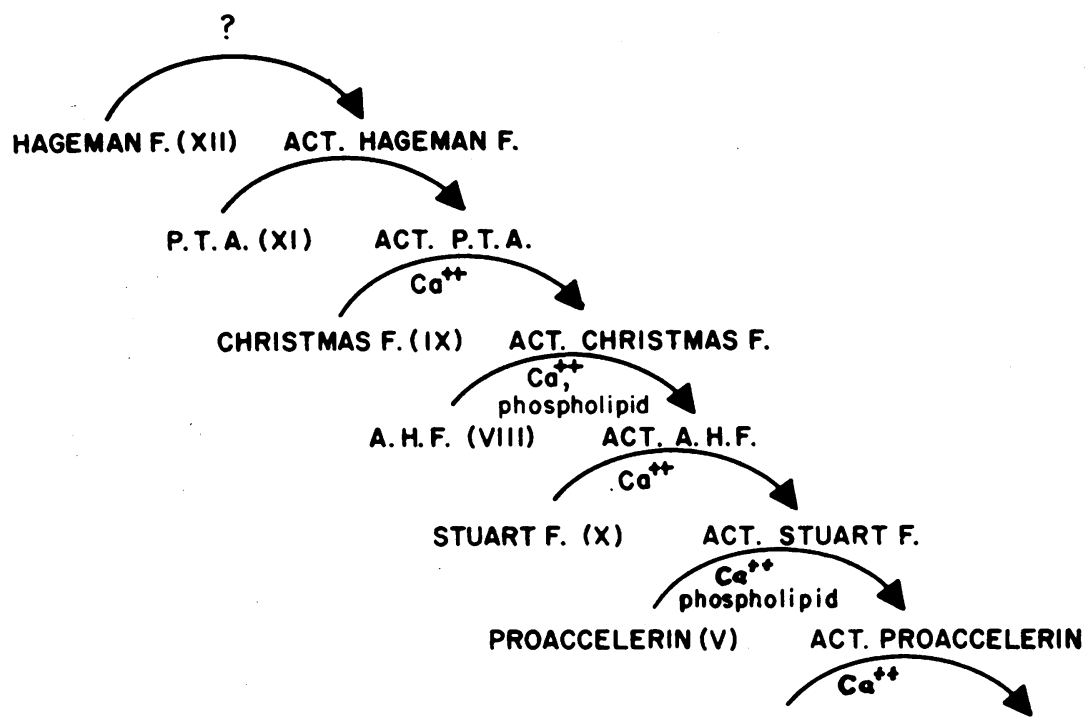

PROTHROMBIN (II) THROMBIN

FIBRINOGEN (I) FIBRIN

Fig. 4. Tentative mechanism for the initiation of blood clotting in mamMALIAN PLASMA IN THE INTRINSIC SyStem. Modified from Macfarlane (35) and Davie and Ratnoff (36). PTA = plasma thromboplastin antecedent; $\mathrm{AHF}=$ antihemophilic factor.

tire known intrinsic coagulation scheme and has been postulated previously $(35,36)$.

Calcium ions are necessary for the interaction of the activated Stuart factor and proaccelerin. This reaction can take place in the presence of citrate, but, as pointed out by Hastings and coworkers (37), appreciable concentrations of free calcium ions are present in solutions of calcium citrate. Studies currently underway in this laboratory have demonstrated an absolute calcium requirement for the conversion of prothrombin to thrombin by activated proaccelerin (32). The conclusions regarding the action of soybean trypsin inhibitor in coagulation differ somewhat from those of other investigators $(38,39)$ since, at the concentrations tested, we were able to localize the anticoagulant effect to a specific stage of coagulation, the formation of the prothrombinconverting principle. Our studies localizing this inhibitor action at the interaction of activated Stuart factor and proaccelerin are consistent with the observations of other investigators (38-44) that, at the concentrations tested here, this inhibitor acts at a stage preceding the formation of thrombin.
The finding that protamine sulfate and Polybrene also impaired this step in coagulation is consistent with previously reported data that these inhibitors have an anticoagulant effect during the development of the prothrombin-converting principle and before the action of thrombin on fibrinogen $(45-47)$.

\section{Summary}

Localization of the site of action of soybean trypsin inhibitor in impeding coagulation has permitted a study of the nature of the interaction between activated Stuart factor and proaccelerin during the formation of the prothrombin-converting principle. The data demonstrate that activated Stuart factor, in the presence of phospholipid and calcium, interacts with proaccelerin to form this prothrombin-converting principle or activated proaccelerin, the concentration of which is dependent upon the amount of proaccelerin present. Soybean trypsin inhibitor, protamine sulfate, and Polybrene impede the interaction between activated Stuart factor and proaccelerin. 


\section{Acknowledgments}

These studies could not have been performed without the expert technical assistance of Miss Gloria Bauer, Mrs. Edna Stone, and Mrs. Robert Smink. Stuart factor-deficient and Christmas factor-deficient plasmas and serums were provided through the courtesy of the late Dr. Paul Hagen and Dr. Stanley Troup, respectively.

We express our appreciation to Dr. Douglas Surgenor and Dr. Earl Davie for their help and criticisms in the preparation of this manuscript. Dr. Earl Davie kindly prepared the diisopropyl fluorophosphate-treated prothrombin-converting principle used in this study, and Dr. $\mathrm{H}$. Milstone was kind enough to allow us to use his preparation of bovine thrombokinase.

\section{References}

1. Owren, P. A. The coagulation of blood. Investigations on a new clotting factor. Acta med. scand. 1947, 128 (suppl.), 194.

2. Ware, A. G., and W. H. Seegers. Serum Ac-globulin; formation from plasma Ac-globulin; role in blood coagulation; partial purification, properties, and quantitative determination. Amer. J. Physiol. 1948, 152, 567.

3. Flynn, J. E., and R. W. Coon. Fundamentals of blood clotting. Ann. Rev. Physiol. 1952, 14, 205.

4. Hjort, P. F. Intermediate reactions in the coagulation of blood with tissue thromboplastin. Convertin, accelerin, prothrombinase. Scand. J. clin. Lab. Invest. 1957, 9 (suppl. 27), 1.

5. Quick, A. J. The assay and properties of labile factor (Factor V). J. clin. Path. 1960, 13, 457.

6. Alexander, B., and R. Goldstein. Parahemophilia in three siblings (Owren's disease) with studies on certain plasma components affecting prothrombin conversion. Amer. J. Med. 1952, 13, 255.

7. Hardisty, R. M. The reaction of blood coagulation factors with brain extract. Brit. J. Haemat. 1955, 1, 323.

8. Straub, W., and F. Duckert. The formation of the extrinsic prothrombin activator. Thrombos. Diathes. haemorrh. (Stuttg.) 1961, 5, 402.

9. Breckenridge, R. T., and O. D. Ratnoff. Studies on the site of action of a circulating anticoagulant in disseminated lupus erythematosus. Evidence that this anticoagulant inhibits the reaction between activated Stuart factor (Factor $\mathrm{X}$ ) and proaccelerin (Factor V). Amer. J. Med. 1963, 35, 813.

10. Surgenor, D. M., N. A. Wilson, and A. S. Henry. Factor V from human plasma. Thrombos. Diathes. haemorrh. (Stuttg.) 1961, 5, 1.

11. Ratnoff, O. D., E. W. Davie, and D. L. Mallett. Studies on the activation of Hageman factor: evidence that activated Hageman factor in turn activates plasma thromboplastin antecedent. J. clin. Invest. 1961, 40, 803.

12. Soulier, J-P. A new adsorption agent for coagulation factors. J. clin. Path. 1959, 12, 303.
13. Hougie, C. A simple assay method for Factor $X$ (Stuart-Prower factor). Proc. Soc. exp. Biol. (N. Y.) 1962, 109, 754.

14. Kimura, E. T., P. R. Young, R. J. Stein, and R. K. Richards. Some pharmacologic characteristics of hexadimethrine bromide (Polybrene); a new antiheparin agent. Toxicol. appl. Pharmacol. 1959, 1, 185.

15. Brenckenridge, R. T., and O. D. Ratnoff. Studies on the nature of the circulating anticoagulant directed against antihemophilic factor: with notes on an assay for antihemophilic factor. Blood 1962, 20, 137.

16. Lepow, I. H., L. Pillemer, and O. D. Ratnoff. The influence of calcium ions on the inactivation of human complement and its components by plasmin. J. exp. Med. 1953, 98, 277.

17. Macfarlane, R. G. The coagulant action of Russell's viper venom: the use of anti-venom in defining its reaction with a serum factor. Brit. J. Haemat. 1961, 7, 496.

18, Spaet, T. H., and J. Cintron. Pathways to blood coagulation product I formation. Blood 1963, 21, 745.

19. Peden, J. C., Jr., and A. C. Peacock. The coagulation of blood by Russell's viper venom. A reaction between Russell's viper venom and beef serum factors. J. Lab. clin. Med. 1958, 52, 101.

20. Williams, W. J., and M. P. Esnouf. The fractionation of Russell's-viper (Vipera Russellii) venom with special reference to the coagulant protein. Biochem. J. 1962, 84, 52.

21. Esnouf, M. P., and W. J. Williams. The isolation and purification of a bovine-plasma protein which is a substrate for the coagulant fraction of Russell's-viper venom. Biochem. J. 1962, 84, 62.

22. Bergsagel, D. E., and C. Hougie. Intermediate stages in the formation of blood thromboplastin. Brit. J. Haemat. 1956, 2, 113.

23. Hougie, C. The role of Factor $\mathrm{V}$ in the formation of blood thromboplastin. J. Lab. clin. Med. 1957, $50,61$.

24. Bordet, J., and O. Gengou. Sur le pouvoir coagulant du sérum. Ann. Inst. Pasteur 1904, 18, 98.

25. Milstone, J. H. On the evolution of blood clotting theory. Medicine (Baltimore) 1952, 31, 411.

26. Morawitz, P. Beiträge zur Keuntius der Blutgerinning. Dtsch. Arch. klin. Med. 1904, 79, 1.

27. Milstone, J. H. Thrombokinase of the blood as a trypsin-like enzyme. J. gen. Physiol. 1962, 45, 103.

28. Nolf, $P$. Contribution à l'étude de la coagulation du sang. ( $3^{\circ}$ mémoire) Les facteurs prim ordiaux, leur origine. Arch. int. Physiol. 1908, 6, 1.

29. Howell, W. H. The role of antithrombin and thromboplastin (thromboplastic substance) in the coagulation of blood. Amer. J. Physiol. 1911, 29, 187.

30. Owren, P. A. Prothrombin and accessory factors; clinical significance. Amer. J. Med. 1953, 14, 201. 
31. Seegers, W. H., and E. Marciniak. Autoprothrombin $\mathrm{C}$ in irregular blood clotting. Thrombos. Diathes. haemorrh. (Stuttg.) 1962, 8, 1.

32. Breckenridge, R. T., and O. D. Ratnoff. Unpublished observations.

33. Papahadjopoulos, D., C. Hougie, and D. J. Hanahan. Purification and properties of bovine Factor V: a change of molecular size during blood coagulation. Biochemistry 1964, 3, 264.

34. Milstone, J. H., N. Oulianoff, and V. K. Milstone. Outstanding characteristics of thrombokinase isolated from bovine plasma. J. gen. Physiol. 1963, 47, 315.

35. Macfarlane, R. G. An enzyme cascade in the blood clotting mechanism, and its function as a biochemical amplifier. Nature (Lond.) 1964, 202, 498.

36. Davie, E. W., and O. D. Ratnoff. Waterfall sequence for intrinsic blood clotting. Science 1964, $145,1310$.

37. Hastings, A. B., F. C. McLean, L. Eichelberger, J. L. Hall, and E. Da Costa. The ionization of calcium, magnesium and strontium citrates. J. biol. Chem. 1934, 107, 351.

38. Glendening, M. B., and E. W. Page. The site of inhibition of blood clotting by soy bean trypsin inhibitor. J. clin. Invest. 1951, 30, 1298.

39. Shulman, N. R., and J. Z. Hearon. Kinetics of conversion of prothrombin to thrombin by biological activators. I. Demonstration of a prothrombin derivative which reacts with proteolytic enzyme inhibitors. J. biol. Chem. 1963, 238, 155.

40. Milstone, J. H. Effect of blood thrombokinase as influenced by soybean trypsin inhibitor, ultracentrifugation, and accessory factors. J. gen. Physiol. $1955,38,757$.

41. Macfarlane, R. G., and J. Pilling. Anticoagulant action of soybean trypsin inhibitor. Lancet 1946, 250, 888.

42. Tagnon, H. J., and J. P. Soulier. Anticoagulant activity of the trypsin inhibitor from soya bean flour. Proc. Soc. exp. Biol. (N. Y.) 1946, 61, 440.

43. Glazko, A. J. Effect of blood protease and trypsin inhibitor on the clotting mechanism. J. clin. Invest. $1947,26,364$.

44. Markwardt, F., A. Hoffman, and H. Landmann. Versuche zur Hemmung der Autoprothrombin C-Wirkung. Thrombos. Diathes. haemorrh. (Stuttg.) 1964, 11, 230.

45. Chargaff, E., and K. B. Olson. Studies on the chemistry of blood coagulation; studies on action of heparin and other anticoagulants. Influence of protamine on anticoagulant effect in vivo. J. biol. Chem. 1937, 122, 153.

46. Hougie, C. Anticoagulant action of protamine sulfate. Proc. Soc. exp. Biol. (N. Y.) 1958, 98, 130.

47. Shanberge, J. N., E. E. Regan, L. Talarico, and B. Busiek. The effect of polybrene on blood coagulation. In vitro. J. Lab. clin. Med. 1961, 58, 23. 